\title{
Particle Densities of Horticultural Substrates
}

Paul C. Bartley III

Department of Horticultural Sciences, North Carolina State University, Raleigh, NC 27695

Aziz Amoozegar

Department of Crop and Soil Sciences, North Carolina State University, Raleigh, NC 27695

\section{William C. Fonteno and Brian E. Jackson \\ Department of Horticultural Sciences, North Carolina State University, Raleigh, NC 27695}

Additional index words. active porosity, coconut coir, peat, perlite, pine bark, physical properties, pycnometer, total porosity, wood

\begin{abstract}
The heterogeneity of horticultural substrates makes basic physical characteristics, such as total porosity and particle density, difficult to estimate. Due to the material source, inclusion of occluded pores, and hydrophobicity, particle density values reported from using liquid pyknometry, vary widely. Gas pycnometry was used to determine the particle density of coir, peat, perlite, pine bark, and wood substrates. Further precision was examined by gas species and separation by particle size. The calculated particle densities for each material determined by $\mathrm{He}, \mathrm{N}_{2}$, and air were relatively constant and varied little despite the species of gas used. Particle size affected the measured particle density of perlite and pine bark but was minimal with coir, peat, and wood. Reducing the particle size removed more occluded pores and the measured particle density increased. Given the small variability, the use of particle density values obtained by gas pycnometry provides repeatable, precise measurements of substrate material total porosity.
\end{abstract}

Horticultural container substrates generally yield complex pore geometries spanning interparticle and intraparticle voids (Bartley et al., 2019). Intraparticle pores can be active or inactive contributors to gas and water exchanges relative to their occlusion within the substrate interparticle pore matrix. Occluded pores within particles make up the inactive porosity (IP), whereas the connected pores make up the effective or active porosity (AP) (Bunt, 1984; Ordovas and Carmona, 1996). Combined, the IP and AP make up the total porosity (TP) of a substrate. The heterogeneity in the pore distribution in substrates makes basic physical characteristics, such as TP and particle density, ambiguous depending on the material and the procedure by which these properties are evaluated.

A common procedure for estimating the AP of container substrates measures porosity indirectly via saturation methods, such as the one described in the NCSU Porometer Method (Fonteno et al., 1995). This procedure

Received for publication 20 Oct. 2021. Accepted for publication 29 Nov. 2021.

Published online 28 January 2022.

P.B. III is currently Assistant Professor in the Department of Horticulture, Auburn University, Auburn, AL 36849.

P.B. III is the corresponding author. E-mail: paul.bartley@auburn.edu.

This is an open access article distributed under the CC BY-NC-ND license (https://creativecommons. org/licenses/by-nc-nd/4.0/). requires specific cores, base plates, and draining wells to calculate total porosity by water displacement. The accuracy of this method, however, hinges on the ability of the liquid to penetrate the connected voids that make up the AP of the substrate. Discrepancies in the results could be attributed to the exclusion of some of the connected interparticle pores due to air entrapment and the hydrophobic tendencies of some organic components such as peat or pine bark (Bunt, 1984; Fields et al., 2014). Therefore, this method may characterize only the porosity contributing to water exchange rather than the AP.

The fraction void space (i.e., porosity) can also be estimated through the following calculation:

$$
\text { porosity }=\left(1-\rho_{\mathrm{b}} / \rho_{\mathrm{s}}\right),
$$

where $\rho_{\mathrm{b}}$ is the bulk density and $\rho_{\mathrm{s}}$ is the particle density of the material. This equation estimates the TP when $\rho_{\mathrm{s}}$ is the true density of the ground mass of material and AP when $\rho_{\mathrm{s}}$ is the apparent particle density of the substrate measured in their current state. To determine TP or AP, the particle density of organic substrates is often estimated (e.g., $1.55 \mathrm{~g} \cdot \mathrm{cm}^{-3}$ ), but the estimated values may not be universally accurate for the substrates under consideration (de Boodt et al., 1974; Gabriëls and Verdonck, 1991; Gras, 1987).

Rather than using an estimated value, particle density can be measured directly by volume displacement techniques such as liquid or gas pycnometry methods commonly used for soil and other porous materials [American Society for Testing Materials (ASTM), 2020a, 2020b; Flint and Flint, 2002]. When determining the particle density by volume displacement, the volume of occluded pores (and/or IP) may be included as part of the solid fraction. We refer to the particle density determined by volume displacement as its apparent particle density or envelope density, and using it in Eq. [1] gives the value for AP. The true particle density excludes occluded pores as part of the solid volume and can be measured after grinding the material finely to expose most if not all pores.

Measurement of particle density of horticultural substrates by liquid displacement have yielded varied results (Table 1). The variability observed in the values reported in literature could be due to the original source of the samples, exclusion of some of the connected interparticle pores due to air entrapment, the propensity of substrate materials to float in liquid, and water repellency due to the hydrophobic tendencies of some organic components such as peat or pine bark (Bunt, 1984; Fields et al., 2014).

Gas pycnometry is a well-established method that uses the Boyle's ideal gas law to measure the volume of the solid fraction. Using a gas species such as helium (He), the particle density of organic and inorganic substrate components has been measured with high repeatability and noted advantages over liquid displacement techniques (Bartley et al., 2020; Ordovas and Carmona, 1996). Although He has been recommended for determining particle density of soils, it may demonstrate some measurable permeability through low-density solids (cellulosic materials), thus interfering with measurement (ASTM, 2020a; Flint and Flint, 2002; Haugen and Bertoldi, 2017). In addition to $\mathrm{He}$, nitrogen $\left(\mathrm{N}_{2}\right)$ and atmospheric air, composed of $\approx 78 \% \mathrm{~N}_{2}$ and $21 \%$ oxygen $\left(\mathrm{O}_{2}\right)$, as well as vacuum, have been recommended for use by some gas pycnometer manufacturers (e.g., UGT, Müncheberg, Germany; Micromeritics, Norcross, GA; Quantochrome Instruments, Boynton Beach, FL). Atmospheric air has been used to determine particle density of soil (ten Damme et al., 2021). The use of different gas species for assessing particle density of different horticultural substrate, however, has not been investigated.

As a result of the unique properties of substrate components, gas pycnometry may be the most appropriate method for accurately determining their TP and particle density. The objective of this work was to measure particle density of selected organic and inorganic substrate components and relate them to particle structure, size, and the species of gas used in gas pycnometry.

\section{Materials and Methods}

Coir, peat, and pine bark, three common substrate base components as well as perlite and wood chips, two substrate additives were selected for analysis. Coir (Oldcastle; Anderson, SC) material was obtained in brick form, hydrated to $60 \%$ moisture content by mass, 
Table 1. Published particle density values $\left(\rho_{\mathrm{s}}\right)$ for organic and inorganic substrate components determined by liquid displacement technique.

\begin{tabular}{llcl}
\hline Component & \multicolumn{1}{c}{ Material description } & $\rho_{\mathrm{s}}\left(\mathrm{g} \cdot \mathrm{cm}^{-3}\right)$ & \multicolumn{1}{c}{ Source } \\
\hline Peat & Sphagnum peat & 1.40 & Paivanen (1973) \\
& White peat & 1.45 & DeBoodt and Verdonck (1972) \\
& Sphagnum peat & 1.51 & Heiskanen (1992) \\
& Peat & 1.51 & Arenas et al. (2002) \\
& Jiffy-7 & 1.60 & Gislerod (1982) \\
\multirow{5}{*}{ Bark } & Peat moss & 2.00 & Beardsell et al. (1979) \\
& White fir bark & 1.19 & Jenkins and Jarrell (1989) \\
Wood & Pine bark (Pinus radiata) & 1.28 & Beardsell et al. (1979) \\
& Sawdust (Eucalyptus regnans) & 1.12 & Beardsell et al. (1979) \\
& Sawdust (P. radiata) & 1.42 & Goh and Haynes (1977) \\
Coconut coir & 1.50 & DeBoodt and Verdonck (1972) \\
& Sawdust & 0.76 & Asiah et al. (2004) \\
Perlite & Coir dust & 1.54 & Arenas et al. (2002) \\
& Coir & 2.30 & DeBoodt and Verdonck (1972) \\
\hline
\end{tabular}

and broken up by hand. In a similar fashion, sphagnum peat (BPP; Berger, Saint-Modeste, Canada) was acquired and prepared. The pine bark (Pinus palustris) analyzed in this study was aged for 3 months. Wood particles within the pine bark material were removed by hand. Soil collected by the bark during the aging process was separated by a series of drying and washing events (Kaderabek et al., 2017). Pine trees (Pinus taeda) located in Raleigh, NC, were harvested (bark removed), chipped, and sieved to acquire wood particles between a 1- and 4-mm screen size. Horticultural perlite (Krum; Carolina Perlite Company, Gold Hill, NC) was wet to a moisture content of $25 \%$ by mass and mixed thoroughly before sampling.

All five materials were evaluated in two states, whole and ground, to assess their particle density as well as occluded porosity. For the first set of analysis, $120-\mathrm{cm}^{3}$ bulk samples $(n=3)$ of the whole material from each substrate were collected. These samples were oven-dried at $105^{\circ} \mathrm{C}$ for $24 \mathrm{~h}$ and then stored in a desiccator (with $\mathrm{CaCl}_{2}$ as desiccant) under vacuum before particle density analysis using three gases. The time and temperature used to dehydrate the materials below detectable ( $<5 \%$ moisture content, w:w) was confirmed using an oven-style moisture analyzer (MB 120, Ohaus, Parsippany, NJ). To assess the true density vs. apparent particle density of the materials, additional bulk samples were prepared similarly, ground in a coffee grinder with a metallic blade, and passed through a $0.5-\mathrm{mm}$ sieve. Ground samples and new whole material samples $(n=3)$ were analyzed. Additional bulk samples of pine bark and perlite, which contain a suspected high volume of occluded pores, were also collected and separated by particle size after passing them through a nest of 12.5-, 4.5-, 2-, 1-, and 0.5$\mathrm{mm}$ sieves. Similar to the procedure used for the whole samples, these samples were oven dried and kept in a desiccator under vacuum before measuring their particle density.

Particle density measurements were made by a commercial gas pycnometer (AccuPyc II 1340, Micromeritics Instrument Corp.) using research grade compressed helium $(\mathrm{He})$, nitrogen $\left(\mathrm{N}_{2}\right)$, and dry air (referred to as zero air). Only $\mathrm{He}$ was used to measure
Table 2. Particle density $\left(\rho_{\mathrm{s}}\right)$ and coefficient of variance $(\mathrm{CV})$ of whole substrate components measured by gas pycnometry using $\mathrm{He}$, dry air, and $\mathrm{N}_{2}$ gas.

\begin{tabular}{lccc}
\hline Material $^{\mathrm{z}}$ & Gas species & $\rho_{\mathrm{s}}\left(\mathrm{g} \cdot \mathrm{cm}^{-3}\right)$ & $\mathrm{CV}(\%)$ \\
\hline Coir & $\mathrm{He}$ & $1.43 \mathrm{~b}^{\mathrm{y}}$ & 0.7 \\
& Air $^{\mathrm{x}}$ & $1.48 \mathrm{a}$ & 0.9 \\
Peat & $\mathrm{N}_{2}$ & $1.46 \mathrm{ab}$ & 1.2 \\
& $\mathrm{He}$ & $1.40 \mathrm{~b}$ & 0.5 \\
& $\mathrm{Air}$ & $1.42 \mathrm{~b}$ & 0.5 \\
Perlite & $\mathrm{N}_{2}$ & $1.46 \mathrm{a}$ & 0.5 \\
& $\mathrm{He}$ & $0.67 \mathrm{NS}$ & 8.8 \\
& $\mathrm{Air}$ & 0.67 & 9.1 \\
Pine bark & $\mathrm{N}_{2}$ & 0.67 & 9.3 \\
& $\mathrm{He}$ & $1.20 \mathrm{a}$ & 0.7 \\
& $\mathrm{Air}$ & $1.08 \mathrm{~b}$ & 0.5 \\
Wood & $\mathrm{N}_{2}$ & $1.08 \mathrm{~b}$ & 1.0 \\
& $\mathrm{He}$ & $1.38 \mathrm{~b}$ & 0.3 \\
& $\mathrm{Air}$ & $1.38 \mathrm{~b}$ & 0.2 \\
& $\mathrm{~N}_{2}$ & $1.40 \mathrm{a}$ & 0.2 \\
\hline
\end{tabular}

particle density of all ground samples and different size fractions of perlite and pine bark. Each day, a sample of known volume (standard) was used to check the accuracy of the internal calibration of the gas pycnometer before analyzing volume of the solids in the samples. On the basis of the accuracy of measured volume of the standard sample, no recalibration of the equipment was needed during the study. The instrument's $100-\mathrm{cm}^{3}$ sample container was loose filled to the top with oven-dried material and weighed before analysis. Each sample was automatically purged 10 times followed by 10 consecutive measurements of its true volume at an initial pressure of $\approx 134 \mathrm{kPa}$ (manufacturer recommendation). The individual measured values of the volume as well as their mean and standard deviation were recorded. The mass of each sample was divided by the mean volume of its 10 runs to calculate particle density.

All statistical analyses were performed using SAS 9.4 (SAS Institute, Cary, NC). The particle density values by material and gas species were subject to PROC GLM and analyzed as individual experiments by material. The interaction between material and state (whole or ground) was also subject to PROC GLM. The LSMEANs within the analysis of variance were adjusted by Tukey's multicomparison test and sliced by material. A polynomial regression was used to characterize the relationship between particle size and particle density for perlite and pine bark.

\section{Results}

Particle density by gas species. Little variability (cv range of $0.2 \%$ to $1.2 \%$ ) between the particle densities of three replications were recorded for each of the organic substrates (Table 2). The only exception was perlite, a mineral ore expanded under high heat which generates significant internal porosity, which had a modest particle density cv of $\approx 9 \%$, which is still considered low variability.

Gas species effects on the measured particle density of the materials differed. For example, the particle density of pine bark measured with air and nitrogen were the same, $1.08 \mathrm{~g} \cdot \mathrm{cm}^{-3}$, which is not surprising because air is composed of $\approx 78 \% \mathrm{~N}_{2}$ and $20 \% \mathrm{O}_{2}$.
${ }^{\mathrm{z}}$ Materials evaluated in a whole, unchanged state.

${ }^{\mathrm{y}}$ Statistical comparisons within a column by material followed by the same letter are not significantly different (Tukey test, $P \leq 0.05$ ). Each material was treated as an individual experiment. ${ }^{\mathrm{x}}$ Dry air or zero air comprising $\approx 78 \% \mathrm{~N}_{2}$ and $20 \% \mathrm{O}_{2}$

The highest particle density for pine bark, $1.20 \mathrm{~g} \cdot \mathrm{cm}^{-3}$, was obtained using He. The higher particle density (i.e., lower solid volume for a given mass of material) of pine bark could be attributed to the ability of the $\mathrm{He}$ gas, a much smaller molecule than $\mathrm{N}_{2}$ (and $\mathrm{O}_{2}$ ), to enter small intraparticle pore spaces, or possible instantaneous adsorption and desorption of $\mathrm{He}$ on the pine bark. Small differences among the particle densities of each of the other substrates determined by the three gases indicates that any of the three gases may be used to determine particle density.

Particle density in whole vs. ground states. If occluded pores are present in a material, the resulting particle density in a whole, unchanged state would be lower than when the material is ground. This can have an impact on the estimated porosity of the material using Eq. [1]. Comparison between whole and ground states may provide a measure of occluded pores of the sample. Considering the similarity of the particle density values of the substrates determined by the three gases (see Table 2), only He, the standard and recommended species for gas pycnometry to analyze soil (ASTM, 2020a; Flint and Flint, 2002), was used to determine the particle density of whole and ground samples (Table 3). Overall, the values obtained for the whole samples of each substrate presented in Table 3 are similar to their corresponding values reported in Table 2.

The differences between the particle densities of peat and wood in a whole and ground state are $0.7 \%$ and $2.1 \%$, respectively. Considering these relatively small differences between whole and ground samples, peat and wood substrates may contain a few occluded, intraparticle pores. The differences between the particle densities for whole and ground coir, pine bark, and perlite were $4.7 \%$, 
Table 3. Particle density $\left(\rho_{\mathrm{s}}\right)$ and coefficient of variance (cv) of whole and ground substrate components measured by gas pycnometry using $\mathrm{He}$.

\begin{tabular}{llcc}
\hline Material & \multicolumn{1}{c}{ State } & $\rho_{\mathrm{s}}\left(\mathrm{g} \cdot \mathrm{cm}^{-3}\right)$ & $\mathrm{Cv} \mathrm{( \% )}$ \\
\hline Coir & Whole & 1.48 & 0.7 \\
& Ground & 1.55 & 1.9 \\
& Significance & $* * *$ & \\
Peat & Whole & 1.41 & 0.6 \\
& Ground & 1.41 & 0.3 \\
& Significance & $\mathrm{NS}$ & \\
Perlite & Whole & 0.64 & 7.0 \\
& Ground & 2.11 & 1.0 \\
& Significance & $* * *$ & \\
Pine bark & Whole & 1.28 & 1.8 \\
& Ground & 1.44 & 0.2 \\
\multirow{4}{*}{ Wood } & Significance & $* * *$ & \\
& Whole & 1.38 & 0.1 \\
& Ground & 1.41 & $<0.1$ \\
& Significance & Ns & \\
\hline
\end{tabular}

$\mathrm{NS}, * * *$ Nonsignificant or significant differences within each material by state at $\alpha=0.001$, respectively.

$11.1 \%$, and $69.7 \%$, respectively. These differences, notably for pine bark and most significantly for perlite, indicate substantial amounts of occluded, intraparticle pore spaces are present. Variability in particle density values for the ground state of pine bark and perlite as determined by their respective cvs were smaller than their corresponding cv for whole samples. This is most likely due to the inherent variability in the whole form for both materials.

Particle density by particle size. The particle density of perlite and pine bark, having more occluded pores, were analyzed by particle size. For a more precise determination of particle density by particle size, the average size of particles captured in each sieve, rather than the sieve aperture size, was used for analysis. Average particle size was assumed to be the average of the width of the sieve aperture that captured the particle and the adjacent (larger) sieve aperture. For example, particles passing a $2-\mathrm{mm}$ sieve and retained in a $1-\mathrm{mm}$ sieve were assumed to have a mean diameter of $1.5 \mathrm{~mm}$. With no adjacent size for the largest and smallest sieves, particles captured in the $12.5-\mathrm{mm}$ sieve were assumed to have a diameter of $19 \mathrm{~mm}$, and particles that passed $0.5-\mathrm{mm}$ sieve were assumed to have an average size of $0.25 \mathrm{~mm}$.

The relationship between particle size and particle density was quadratic for both pine bark and perlite (Fig. 1). The apparent particle density values for pine bark decreased from $<0.5$ - to $<12.5-\mathrm{mm}$ particles but showed a slight increase for particles $>12.5 \mathrm{~mm}$. The particle density for pine bark $>12.5 \mathrm{~mm}$ (1.21 $\mathrm{g} \cdot \mathrm{cm}^{-3}$ ) was $\approx 11 \%$ higher than the 4.75 - to $12.5-\mathrm{mm}$ particle class $\left(1.08 \mathrm{~g} \cdot \mathrm{cm}^{-3}\right)$. Like pine bark, the particle density values for perlite decreased as particle size increased from $<0.5$ to $<4.75 \mathrm{~mm}$ but showed a slight increase for particles $>4.75 \mathrm{~mm}$. The particle density for the perlite $>4.75 \mathrm{~mm} \quad(0.66$ $\mathrm{g} \cdot \mathrm{cm}^{-3}$ ) was $\approx 9 \%$ higher than the corresponding value for particles in the 2.00- to $4.75-\mathrm{mm}$ particle class $\left(0.60 \mathrm{~g} \cdot \mathrm{cm}^{-3}\right)$. No a.
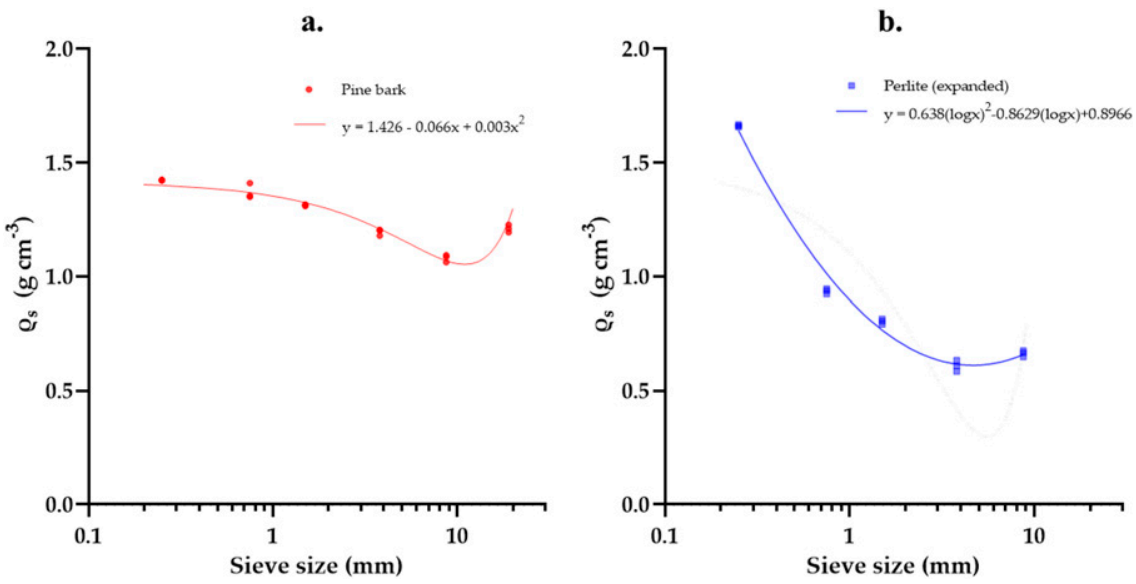

Fig. 1. Particle density $\left(\rho_{\mathrm{s}}\right)$ by particle size for pine bark (A) and perlite (B) obtained by gas pycnometry using helium.

perlite was captured by the $12.5-\mathrm{mm}$ sieve. For reference, the particle density of perlite ore aggregates (averaged for three replications) was $2.30 \mathrm{~g} \cdot \mathrm{cm}^{-3}$ with a cv of $0.03 \%$. This indicates that even the smallest perlite particles $(<0.5-\mathrm{mm}$ diameter $)$ that were analyzed have some occluded pores that are formed during the formation of perlite substrate from the parent material.

The correlation coefficients of the quadratic functions describing the relationship between particle density and particle size for pine bark and perlite were 0.97 and 0.98 , respectively. These functions were determined on a linear scale for pine bark and a log-transformed scale for perlite. The use of these functions to estimate particle density for pine bark and perlite should only be done within constraints of the particle size range evaluated in this study.

\section{Discussion}

Specific particle sizes in engineered (premixed) container substrates are often selected for desirable physical and hydrological characteristics (Altland et al., 2017; Fields et al., 2014,2018 ). The use of generic or estimated particle density values for these materials may result in an incorrect estimation of their AP or TP. Thus, by knowing the particle density of different size fractions of substrate components, a better estimated value for AP or TP can be obtained. This is particularly true for perlite and pine bark components.

Horticultural-grade perlite is expanded or "popped" as a result of the expanding water content in the ore when heated. With the exception of particles larger than $\approx 5 \mathrm{~mm}$, smaller, expanded perlite particles would have fewer occluded pores than larger diameter particles, lower surface area to volume ratios, and a particle density which approaches that of the perlite ore $\left(2.30 \mathrm{~g} \cdot \mathrm{cm}^{-3}\right)$. Larger perlite ore aggregates would theoretically require higher temperatures or a longer duration in the furnace to fully expand. Therefore, it is possible that the largest expanded perlite particles contain slightly unaltered regions resulting in a relatively higher particle density.

Pine bark is a tissue comprising expanded parenchyma, crushed phloem, and dense layers of periderm. This tissue layer acts as a thermal insulator and storage for plant byproducts and impurities, such as tannins and resinous substances. Pine bark is frequently aged to break down these byproducts, which may affect plant growth (Kaderabek, 2017). Larger particles could provide more resistance to the degradation of these compounds. Thus, fewer occluded pores could be present in large pine bark particles resulting in an increase in particle density for bark pieces with a dimension $>1.2 \mathrm{~cm}$. Alternatively, the chemical composition of pine bark by size could vary due to the heterogeneity of bark constituents (phloem, cork, periderm).

Despite the variability within perlite and pine bark substrates, reasonable estimations of AP may still be calculated using particle density. Particle size distribution is a common metric used to characterize substrates. If the geometric mean (volume-based, not massbased) particle size can be determined, the mean particle density of the sample can be derived using the polynomial equations provided in Fig. 1.

For materials such as coir, peat, and wood, which contain few to no apparent occluded pores, a generic value may be considered. Coir particle densities reported in literature range from 0.76 to $1.54 \mathrm{~g} \cdot \mathrm{cm}^{-3}$ with the latter being more similar to the range of values determined in this study, 1.43 to $1.55 \mathrm{~g} \cdot \mathrm{cm}^{-3}$ (Arenas et al., 2002; Goh and Haynes, 1977). The range of peat particle density values obtained in this study is similar to some densities derived in other studies by liquid pycnometry, but different from those reported by Beardsell et al. (1979), $2.00 \mathrm{~g} \cdot \mathrm{cm}^{-3}$ (de Boodt and Verdonck, 1972; Paivanen, 1973). Previously reported particle densities of wood suggests that particle density may vary by wood species (Beardsell et al., 1979; de Boodt and Verdonck, 1972; Goh and Haynes, 1977). However, particle density values within a 
Table 4. Active porosity of single substrate components derived from particle density and bulk density.

\begin{tabular}{|c|c|c|c|c|c|c|c|}
\hline & & Sand & Peat & Pine bark & Coir & Wood fiber & Perlite \\
\hline & & \multicolumn{6}{|c|}{ Particle density $\left(\mathrm{g} \cdot \mathrm{cm}^{-3}\right.$ solids $)$} \\
\hline & & 2.65 & 1.40 & 1.20 & 1.40 & 1.40 & 0.65 \\
\hline \multirow{28}{*}{$\begin{array}{l}\text { Bulk density } \\
\left(\mathrm{g} \cdot \mathrm{cm}^{-3} \text { total }\right)\end{array}$} & 0.04 & $98.5 \%$ & $97.1 \%$ & $96.7 \%$ & $97.1 \%$ & $97.1 \%$ & $93.8 \%$ \\
\hline & 0.06 & $97.7 \%$ & $95.7 \%$ & $95.0 \%$ & $95.7 \%$ & $95.7 \%$ & $90.8 \%$ \\
\hline & 0.08 & $97.0 \%$ & $94.3 \%$ & $93.3 \%$ & $94.3 \%$ & $94.3 \%$ & $87.7 \%$ \\
\hline & 0.10 & $96.2 \%$ & $92.9 \%$ & $91.7 \%$ & $92.9 \%$ & $92.9 \%$ & $84.6 \%$ \\
\hline & 0.12 & $95.5 \%$ & $91.4 \%$ & $90.0 \%$ & $91.4 \%$ & $91.4 \%$ & $81.5 \%$ \\
\hline & 0.14 & $94.7 \%$ & $90.0 \%$ & $88.3 \%$ & $90.0 \%$ & $90.0 \%$ & $78.5 \%$ \\
\hline & 0.16 & $94.0 \%$ & $88.6 \%$ & $86.7 \%$ & $88.6 \%$ & $88.6 \%$ & $75.4 \%$ \\
\hline & 0.18 & $93.2 \%$ & $87.1 \%$ & $85.0 \%$ & $87.1 \%$ & $87.1 \%$ & $72.3 \%$ \\
\hline & 0.20 & $92.5 \%$ & $85.7 \%$ & $83.3 \%$ & $85.7 \%$ & $85.7 \%$ & $69.2 \%$ \\
\hline & 0.22 & $91.7 \%$ & $84.3 \%$ & $81.7 \%$ & $84.3 \%$ & $84.3 \%$ & $66.2 \%$ \\
\hline & 0.24 & $90.9 \%$ & $82.9 \%$ & $80.0 \%$ & $82.9 \%$ & $82.9 \%$ & $63.1 \%$ \\
\hline & 0.26 & $90.2 \%$ & $81.4 \%$ & $78.3 \%$ & $81.4 \%$ & $81.4 \%$ & $60.0 \%$ \\
\hline & 0.28 & $89.4 \%$ & $80.0 \%$ & $76.7 \%$ & $80.0 \%$ & $80.0 \%$ & $56.9 \%$ \\
\hline & 0.30 & $88.7 \%$ & $78.6 \%$ & $75.0 \%$ & $78.6 \%$ & $78.6 \%$ & $53.8 \%$ \\
\hline & 0.32 & $87.9 \%$ & $77.1 \%$ & $73.3 \%$ & $77.1 \%$ & $77.1 \%$ & $50.8 \%$ \\
\hline & 0.34 & $87.2 \%$ & $75.7 \%$ & $71.7 \%$ & $75.7 \%$ & $75.7 \%$ & $47.7 \%$ \\
\hline & 0.36 & $86.4 \%$ & $74.3 \%$ & $70.0 \%$ & $74.3 \%$ & $74.3 \%$ & $44.6 \%$ \\
\hline & 0.38 & $85.7 \%$ & $72.9 \%$ & $68.3 \%$ & $72.9 \%$ & $72.9 \%$ & $41.5 \%$ \\
\hline & 0.40 & $84.9 \%$ & $71.4 \%$ & $66.7 \%$ & $71.4 \%$ & $71.4 \%$ & $38.5 \%$ \\
\hline & 1.00 & $62.3 \%$ & $28.6 \%$ & $16.7 \%$ & $28.6 \%$ & $28.6 \%$ & - \\
\hline & 1.10 & $58.5 \%$ & $21.4 \%$ & $8.3 \%$ & $21.4 \%$ & $21.4 \%$ & - \\
\hline & 1.20 & $54.7 \%$ & $14.3 \%$ & $0.0 \%$ & $14.3 \%$ & $14.3 \%$ & - \\
\hline & 1.30 & $50.9 \%$ & $7.1 \%$ & - & $7.1 \%$ & $7.1 \%$ & - \\
\hline & 1.40 & $47.2 \%$ & $0.0 \%$ & - & $0.0 \%$ & $0.0 \%$ & - \\
\hline & 1.50 & $43.4 \%$ & - & - & - & - & - \\
\hline & 1.60 & $39.6 \%$ & - & - & - & - & - \\
\hline & 1.70 & $35.8 \%$ & - & - & - & - & - \\
\hline & 1.80 & $32.1 \%$ & - & - & - & - & - \\
\hline
\end{tabular}

genus (i.e., Pinus) or group within a genus (yellow pine group), may be similar.

These results suggest particle density values of $1.40 \mathrm{~g} \cdot \mathrm{cm}^{-3}$ for coir, peat, and wood (Pinus taeda) can be used to estimate the AP of these substrate components more precisely. The range of particle density values obtained with $\mathrm{He}$ for whole coir ranged from a mean of 1.43 to $1.48 \mathrm{~g} \cdot \mathrm{cm}^{-3}$. An average value of $1.45 \mathrm{~g} \cdot \mathrm{cm}^{-3}$ would be reasonably selected to obtain AP. However, the difference in calculated active porosity when using 1.40 or $1.45 \mathrm{~g} \cdot \mathrm{cm}^{-3}$ at a bulk density of 0.10 $\mathrm{g} \cdot \mathrm{cm}^{-3}$ would be an insignificant $0.02 \%$. To calculate AP more precisely in nursery-grade pine bark and horticultural perlite, particle density values of $1.20 \mathrm{~g} \cdot \mathrm{cm}^{-3}$ for pine bark and $0.65 \mathrm{~g} \cdot \mathrm{cm}^{-3}$ may be used. Percent AP by bulk density were estimated from these data for single-component substrates (Table 4). Multiple component calculations can be made using the following equation:

$$
\begin{aligned}
\text { porosity }= & {\left[1-\rho_{\mathrm{b}} /\left(\rho_{\mathrm{s} 1} \times \mathrm{v} \%_{1}\right)\right.} \\
& \left.+\left(\rho_{\mathrm{s} 2} \times \mathrm{v} \%_{2}\right)+\ldots\right],
\end{aligned}
$$

where $\rho_{\mathrm{b}}$ is the bulk density of the composite sample and $\rho_{\mathrm{s}}$ is the particle density of materials 1 and 2 . The particle density for each component is multiplied by its volume fraction (v\%). For multiple components, please see the simple AP calculator (Supplemental Material). For other calculations for TP or physics derivations, these data suggest using $1.55 \mathrm{~g} \cdot \mathrm{cm}^{-3}$ for coir, $1.40 \mathrm{~g} \cdot \mathrm{cm}^{-3}$ for peat,
$2.30 \mathrm{~g} \cdot \mathrm{cm}^{-3}$ for perlite, $1.45 \mathrm{~g} \cdot \mathrm{cm}^{-3}$ for pine bark, and $1.40 \mathrm{~g} \cdot \mathrm{cm}^{-3}$ for wood (Pinus).

The results of this study demonstrate the accuracy and reproducibility of gas pycnometry to obtain substrate particle density values. Also, nitrogen and air can be used for determining particle density of substrates. Using measured values can result in a better understanding of substrate characteristics. Many components are used to engineer substrates, many of which have yet to be analyzed by gas pycnometry. However, the components, methods, and values demonstrated in this work can improve the measurement and modeling of substrate physical and hydrological properties when combined with traditional techniques.

\section{Literature Cited}

Altland, J.E., J.S. Owen, Jr., B.E. Jackson, and J.S. Fields. 2017. Physical and hydraulic properties of commercial pine-bark substrate products used in production of containerized crops. HortScience 53:1883-1890, https://doi.org/10.21273/ HORTSCI13497-18.

Arenas, M., C.S. Vavrina, J.A. Cornell, E.A. Hanlon, and G.J. Hochmuth. 2002. Coir as an alternative to peat in media for tomato transplant production. HortScience 37:309-312, https:// doi.org/10.21273/HORTSCI.37.2.309.

Asiah, A., R.I. Mohd, K.Y. Mohd, M. Marsiah, and M. Shaharuddin. 2004. Physical and chemical properties of coconut coir dust and oil palm empty fruit bunch and the growth of hybrid heat tolerant cauliflower plant. Pertanika, J. Trop. Agr. Sci. 27:121-133, https://doi.org/ 10.1016/S0960-8524(01)00189-4.

American Society for Testing Materials. 2020b. Standard test method for specific gravity of soil solids by water pycnometer. D854-14. ASTM International, West Conshohocken, PA.

American Society for Testing Materials (ASTM). 2020a. Standard test method for specific gravity of soil solids by gas pycnometer. D5550-14. ASTM International, West Conshohocken, PA.

Bartley, P.C., III, A. Amoozegar, W.C. Fonteno, and B.E. Jackson. 2020. Particle density of substrate components measured by gas pycnometer. Acta Hort. 1273:17-22, https://doi. org/10.17660/ActaHortic.2020.1273.3.

Bartley, P.C., B.E. Jackson, and W.C. Fonteno. 2019. 3-Dimensional characterization of substrates with X-ray microtomography. Acta Hort. 1266:1-6.

Beardsell, D.V., D.G. Nichols, and D.L. Jones. 1979. Physical properties of nursery pottingmixtures. Scientia Hort. 11:1-8, https://doi.org/ 10.1016/0304-4238(79)90048-7.

Bunt, A.C. 1984. Physical properties of mixtures of peats and minerals of different particle size and bulk density for potting substrates. Acta Hort. 150:143-154, https://doi.org/10.17660/ActaHortic. 1984.150.15.

de Boodt, M. and O. Verdonck. 1972. The physical properties of the substrates in horticulture. Acta Hort. 26:37-44, https://doi.org/10.17660/ ActaHortic. 1972.26.5.

de Boodt, M., O. Verdonck, and I. Cappaert. 1974. Method for measuring the water release curve of organic substrates. Acta Hort. 37: 2054-2062, https://doi.org/10.17660/ActaHortic. 1974.37.20.

Fields, J.S., W.C. Fonteno, and B.E. Jackson. 2014. Hydration efficiency of traditional and alternative greenhouse substrate components. HortScience 49:336-342, https://doi.org/10.21273/HORTSCI. 49.3.336.

Fields, J.S., J.S. Owen, Jr., J.E. Altland, M.W. van Iersel, and B.E. Jackson. 2018. Soilless substrate hydrology can be engineered to influence plant water status for an ornamental containerized crop grown within optimal water potentials. J. Amer. Soc. Hort. Sci. 143:268-281, https://doi.org/ 10.21273/JASHS04251-17.

Flint, A.L. and L.E. Flint. 2002. Particle density, p. 229-240. In: J.H. Dane and G.C. Topp (eds.). Methods of Soil Analysis: Part 4. Physical Methods. Soil Sci. Soc. Amer., Madison, WI.

Fonteno, W.C., C.T. Harden, and J.P. Brewster 1995. Procedures for determining physical properties of horticultural substrates using the NC State University porometer. North Carolina State Univ., Hort. Substrates Lab., Raleigh, NC.

Gabriëls, R. and O. Verdonck. 1991. Physical and chemical characterization of plant substrates: Towards a European standardization. Acta Hort. 294:249-259, https://doi.org/10.17660/ActaHortic. 1991.294.27.

Gislerod, H.R. 1982. Physical conditions of propagation media and their influence on the rooting of cuttings. I. Air content and oxygen diffusion at different moisture tensions. Plant Soil 69: 445-456, https://doi.org/10.1007/BF02178609.

Goh, K.M. and R.J. Haynes. 1977. Evaluation of potting media for commercial nursery production of container grown plants. N. Z. J. Agr. Res. 20:363-370, https://doi.org/10.1080/00288233. 1977.10427348

Gras, R. 1987. Propriétés physiques des substrates, p. 79-126. In: D. Blanc (ed.). Les cultures hors sol. INRA, Paris, France.

Haugen, H.J. and S. Bertoldi. 2017. Characterization of morphology-3D and porous structure, $\mathrm{p}$. 27-29. In: M.C. Tanzi and S. Fare (eds.). Characterization of polymeric biomaterials. Woodhead Publishing, Cambridge, MA, https://doi.org/ 10.1016/B978-0-08-100737-2.00002-9. 
Heiskanen, J. 1992. Comparison of three methods for determining the particle density of soil with liquid pycnometers. Commun. Soil Sci. Plant Anal. 23:841-846, https://doi.org/10.1080/0010 3629209368633 .

Jenkins, J.R. and W.M. Jarrell. 1989. Predicting physical and chemical properties of container mixtures. HortScience 24:292-295.
Kaderabek, L.E.B. 2017. Effects of aging on the physical, chemical, and hydrological properties of pine bark substrates. M.S. Thesis, North Carolina State Univ., Raleigh.

Ordovas, J. and E. Carmona. 1996. Characteristics of internal porosity of cork container media. HortScience 31:1177-1179, https://doi.org/ 10.21273/HORTSCI.31.7.1177.
Paivanen, J. 1973. Hydraulic conductivity and water retention in peat soils. Acta For. Fenn. 129:1-75, https://doi.org/10.14214/aff.7563.

ten Damme, L., P. Schjønning, L.J. Munkholm, O. Green, S.K. Nielsen, and M. Lamandé. 2021. Soil structure response to field traffic: Effects of traction and repeated wheeling. Soil Tillage Res. 213 105128, https://doi.org/10.1016/j.still.2021.105128. 